\title{
PENGARUH LAYANAN BIMBINGAN KELOMPOK DENGAN TEKNIK SIMULATION GAMES UNTUK MENINGKATKAN MANAJEMEN WAKTU BELAJAR SISWA KELAS XII SMA NEGERI 9 SEMARANG
}

\author{
The Effect Of Group Counseling Services With Simulation Games Techniques To \\ Improve Learning Time Management Students Of Grade XII SMA Negeri 9 Semarang
}

\author{
Oleh: Ulfa Luthfiyanti*, Supardi**, dan Agus Setiawan*** \\ e-mail: luthfiyantiu@gmail.com
}

\begin{abstract}
ABSTRAK
Penelitian ini dilatar belakangi oleh rendahnya manajemen waktu belajar siswa kelas XII SMA Negeri 9 Semarang yang disebabkan kurangnya kemampuan siswa dalam mengatur waktu belajarnya.Tujuan penelitian ini adalah untuk mengetahui tingkat manajemen waktu belajar siswa kelas XII SMA Negeri 9 Semarang sesudah diberi treatment layanan bimbingan kelompok dengan teknikSimulation Games.Jenis penelitian ini adalah eksperimen dengan metode penelitian true eksperimental design dengan bentuk pretest-posttest control group design. Sampel yang diambil sebanyak 20 dengan menggunakan multistage sampling yang merupakan kombinasi dua sampling yaitu cluster random sampling dan simple random sampling. Desain penelitian yang digunakan adalah pre-test, treatment, post-test. Hasil uji hipotesis diperoleh $t_{\text {hitung }}=2,966$ dengan $t_{\text {tabel }}$ yaitu 2,101. Hal tersebut menunjukan bahwa $\mathrm{t}_{\text {hitung }}=2,966>\mathrm{t}_{\text {tabel }}=2,101$, maka dapat disimpulkan bahwa "ada pengaruh layanan bimbingan kelompok dengan teknik simulation games untuk meningkatkan manajemen waktu belajar siswa kelas XII SMA Negeri 9 Semarang.

Kata Kunci : Bimbingan Kelompok, Teknik Simulation Games, Manajemen Waktu Belajar.

\section{ABSTRACT}

This research is motivated by the low management of student learning time in class XII of SMA Negeri 9 Semarang due to the lack of students' ability to manage their study time. The purpose of this study was to determine the level of learning time management of class XII students of SMA Negeri 9 Semarang after being given treatment with group guidance services using Simulation Games technique. This type of research is an experiment with true experimental design research methods in the form of pretest-posttest control group design. Samples taken as many as 20 using multistage sampling which is a combination of two sampling namely cluster random sampling and simple random sampling. The research design used was pre-test, treatment, post-test. Hypothesis test results obtained tcount $=2.966$ with a table that is 2.101. This shows that tcount $=2.966>$ ttable $=2.101$, it can be concluded that "there is an influence of group guidance services with simulation games techniques to improve the management of student learning time in class XII of SMA Negeri 9 Semarang..
\end{abstract}

Keyword: Group Guidance, Simulation Games Techniques, Learning Time Management

\section{PENDAHULUAN}

Pada masa remaja sering kali terjadi masalah kesulitan manajemen waktu

Ulfa Luthfiyanti*, Supardi**, dan Agus Setiawan***

Fakultas Ilmu Pendidikan

Universitas PGRI Semarang 
belajar hal ini karena kurangnya pemahaman mengenai manajemen waktu. Ketidakmampuan dan kurangnya pemahaman siswa mengenai manajemen waktu dapat menimbulkan dampak yang buruk bagi siswa yaitu, sulitnya membagi waktu antara kegiatan akademik dan non akademik hal ini akan menyebabkan kurangnya kedisiplinan pada siswa. Pemahaman mengenai manajemen waktu akan melatih siswa untuk membentuk pribadi yang disiplin,siswa harus terlatih dalam mengatur jadwal sehari-harinya. Pengaturan waktu yang baik akan membuat siswa mampu mengatur kegiatan belajar dengan kegiatan lainnya. Bagi seorang siswa belajar merupakan suatu kewajiban yang harus mereka lakukan serta menyelesaikan setiap tuntutan tugas yang diberikan kepada siswa seperti mengerjakan tugas dengan tepat waktu, mengerjakan tugas atau PR dirumah.Dengan belajar akan menambah wawasan bagi siswa yang awalnya tidak tahu akan menjadi tahu.

Menurut Slameto (2013:54-60) faktor-faktor yang mempengaruhi belajar banyak jenisnya, tetapi dapat digolongkan menjadi 2 golongan saja, yaitu faktor intern dan faktor ekstern. Faktor intern adalah faktor yang ada dalam diri individu yang sedang belajar, faktor intern dibagi menjadi 3 faktor yaitu faktor jasmaniah (faktor kesehatan, cacat tubuh), Faktor Psikologis (inteligensi, perhatian, minat, bakat, motif, kematangan, kesiapan), dan Faktor kelelahan. Sedangkan factor ekstern yang berasal dari luar individu dibagi menjadi 3 yaitu, Faktor keluarga, Faktor Sekolah, dan Faktor masyarakat. Dari banyaknya faktor yang mempengaruhi belajar, salah satu kelemahan yang dialami siswa adalah Ulfa Luthfiyanti*, Supardi**, dan Agus Setiawan*** Fakultas Ilmu Pendidikan kesulitan dalam mengatur waktu untuk belajar, seringkali ditemui masalah kekurangan waktu bagi siswa menjadi alas an untuk tidak terselesaikannya suatu tugas.

Menurut Haynes (2010:5), manajemen waktu seperti halnya manajemen sumber daya lain mengandalkan analisis dan perencanaan. Guna memahami dan menerapkan prinsip manajamen waktu, seseorang harus mengetahui bukan hanya cara menggunakan waktu, tetapi juga masalah yang seseorang hadapi dalam menggunakannya secara efektif disertai penyebabnya. Dari basis ini, seseorang dapat mempelajari cara meningkatkan efektivitas dan efisiensi melalui investasi waktu yang baik.

Berdasarkan hasil wawancara dengan guru BK SMA Negeri 9 Semarang pada tanggal 11 April 2019, bahwa kondisi siswa kelas XII yang berkaitan dengan manajemen waktu belajar antara lain siswa mengeluh karena banyaknya tugas-tugas sekolah, dan belajar jika ada ulangan saja, selain itu juga banyaknya kegiatan diluar sekolah seperti ekstrakurikuler dan organisasi sehingga siswa kesulitan membagi waktu. Serta hasil wawancara dari 3 orang siswa dengan diperoleh hasil bahwa terkadang mereka mengerjakan tugas dengan system kebut semalam, hampir setiap hari tidak lepas dari tugas-tugas sekolah dan terkadang terlambat dalam mengumpulkan tugas, saat akan ulangan biasanya belajar di pagi harinya. Dari beberapa siswa mereka sudah membuat jadwal kegiatan sehari-hari tetapi kadang tidak berjalan sesuai dengan yang sudah direncanakan, bagi siswa menganggap semua kegiatan dan aktifitasnya itu 
penting sehingga siswa belum mampu memfokuskan dan memprioritaskan suatu tugas tertentu. Hal itu juga diperkuat dengan hasil analisis DCM (Daftar Cek Masalah) diperoleh data Saya belajar tidak teratur waktunya $58,1 \%$, saya sering merasa malas belajar $44,6 \%$, saya belajar kalau ada ulangan 50,0\%. Dari permasalahan yang telah dipaparkan diatas serta didukung dengan jurnal penelitian menunjukan bahwa manajemen waktu bukan hanya mengacu pada pengelolaan waktu tetapi lebih kepada bagaimana individu dapat memanfaatkan waktu itu sendiri untuk menciptakan keseimbangan antara tugas-tugas dengan kegiatan yang lain. Dengan begitu individu akan mampu fokus pada satu tugas serta memprioritaskan apa yang harus segera di selesaikan. Berdasarkan permasalahan yang ada pada siswa kelas XII SMA Negeri 9 Semarang dapat disimpulkan bahwa siswa mengalami permasalahan pada manajemen waktu belajar yang membutuhkan bantuan untuk diberikan pemahaman mengenai manajemen waktu belajar, agar kemampuan siswa dalam mengelola waktu dapat memberikan peningkatan.

Berdasarkan fenomena di atas sebenarnya terdapat beberapa jenis layanan bimbingan dan konseling yang bisa dilakukan untuk meningkatkan pemahaman siswa yang berkaitan dengan manajemen waktu belajar, salah satunya yakni layanan bimbingan kelompok. Bimbingan Kelompok adalah layanan bimbingan yang diberikan dalam suasana kelompok. Gazda (dalam Prayitno dan Erman Amti, 2008: 309) mengemukakan bahwa bimbingan kelompok disekolah merupakan kegiatan informasi kepada Ulfa Luthfiyanti*, Supardi**, dan Agus Setiawan**** Fakultas Ilmu Pendidikan sekelompok siswa untuk membantu mereka menyusun rencana dan keputusan yang tepat.Gazda juga menyebutkan bahwa bimbingan kelompok diselenggarakan untuk memberikan informasi yang bersifat personal, vokasional dan social. Bimbingan kelompok dilaksanakan jika masalah yang dihadapi beberapa murid relatif mempunyai kesamaan atau saling mempunyai hubungan serta mereka mempunyai kesediaan untuk dilayani secara kelompok. Selain itu dengan memberikan layanan bimbingan kelompok dalam suasana kelompok juga dapat dijadikan sebagai media untuk menyampaikan informasi, membantusiswa menyusun rencana dalam menentukan keputusan yang tepat sehingga diharapkan dapat berdampak positif bagi siswa yang nantinya akan mampu meningkatkan kemampuan manajemen waktu belajar. Dengan begitu apabila dinamika kelompok dapat terwujud dengan baik maka anggota kelompok dapat saling membantu dan menerima dengan tulus.

Salah satu teknik dalam layanan bimbingan kelompok adalah teknik simulation games, karena agar lebih efektif dan mudah diterima oleh siswa. Menurut Adams (dalam Romlah 2001:117) simulation games adalah permainan untuk merefleksikan situasisituasi yang terdapat dalam kehidupan yang sebenarnya. Permainan simulasi bertujuan untuk membantu siswa untuk mempelajari pengalaman-pengalaman yang berkaitan dengan aturan-aturan sosial.

Berdasarkan uraian di atas dengan memberikan layanan bimbingan kelompok dengan teknik simulation 
games selain untuk pemberian informasi melalui permainan selain itu juga diharapkan bias membantu siswa menyusun rencana dalam membuat keputusan yang tepat dan berani mengemukakan pendapatnya. Terutama dapat memberikan pengaruh pada permasalahan siswa agar dapat terlepas dari kesulitan dalam manajemen waktu belajar.

\section{Manajemen Waktu Belajar}

Menurut Haynes (2010:5)

Manajemen waktu seperti halnya manajemen sumber daya lain mengandalkan analisis dan perencanaan. Guna memahami dan menerapkan prinsip manajemen waktu, individu harus mengetahui bukan hanya cara menggunakan waktu, tetapi juga masalah yang dihadapi dalam menggunakannya secara efektif disertai penyebabnya. Dari basis ini, individu dapat mempelajari cara meningkatkan efektivitas dan efisiensi melalui investasi waktu yang lebih baik, sedangkan menurut Surya (2014:319) menejelaskan manajemen waktu merupakan suatu tindakan dalam memanfaatkan dan mengendalikan waktu dengan sebaik-baiknya sehingga mencapai hasil seoptimal mungkin. Srijanti (2006:95) Manajemen waktu adalah sebuah aktvitas untuk memanfaatkan waktu yang tersedia dan potensi-potensi yang tertanam dalam diri kita untuk mencapai tujuan-tujuan penting dalam kehidupan kita.

Menurut Slameto (2013:2) Belajar ialah suatu proses usaha yang dilakukan seseorang untuk memperoleh suatu perubahan tingkah laku yang baru secara keseluruhan, sebagai hasil pengalamannya sendiri dalam interaksi dengan lingkungannya. Ulfa Luthfiyanti*, Supardi**, dan Agus Setiawan*** Fakultas Ilmu Pendidikan 
apakah dibuat lebih sederhana, atau diambil sebagian, atau dikeluarkan dari konteksnya. Permainan simulasi dapat dikatakan merupakan gabungan antara teknik bermain peranan dengan teknik diskusi. Dalam permainan simulasi para pemainnya berkelompok dan berkompetensi untuk mencapai tujuantujuan tertentu dengan menaati peraturanperaturan yang ditetapkan bersama. Menurut

Majid (2014:207) langkah-langkah yang harus ditempuh dalam simulasi adalah:

a. Persiapan simulasi, menetapkan topik atau masalah serta tujuan yang hendak dicapai oleh simulasi, memberikan gambaran masalah dalam situasi yang akan disimulasikan, menetapkan pemain yang akan terlibat, memberikan kesempatan siswa untuk bertanya.

b. Pelaksanaan simulasi, simulasi mulai dimainkan oleh pemain, siswa lain mengikuti dan memperhatikan, konselor memberikan bantuan pada pemain yang kesulitan.

c. Penutup, melakukan diskusi baik tentang jalannya simulasi maupun cerita yang disimulasikan, merumuskan kesimpulan.

\section{METODE PENELITIAN}

Penelitian dengan judul pengaruh layanan bimbingan kelompok denganteknik simulation games untuk meningkatkan manajemen waktu belajar siswa kelas XII SMA Negeri 9 Semarang dilaksanakan di SMA Negeri 9 Semarang. Waktu penelitian pada bulan Juli September 2019 pada semester I tahun pelajaran 2019/2020. Metode yang digunakan dalam penelitian ini adalah kuantitatif true eksperimental design. Dalam penelitian ini proses ekperimen pengumpulan data dapat dibagi menjadi tiga tahap yaitu tahap persiapan, tahap pelaksanaan dan tahap pengakhiran. Dimana setiap tahap tersebut memuat beberapa langkah-langkah sebagai berikut:

1. Persiapan Eksperimen

a. Subjek penelitian yang akan diteliti adalah peserta didik kelas XII yang terdiri dari kelas XII MIPA 1, XII MIPA 2, XII MIPA 3, XII MIPA 4, XII MIPA 5, XII MIPA 6, XII MIPA 7, XII IPS 1, XII IPS 2 dan XII IPS 3. Dari jumlah sepuluh kelas tersebut terpilih 3 kelas menggunakan cluster random sampling, yaitu teknik sampling daerah digunakan untuk menentukan sampel bila obyek yang akan diteliti atau sumber data sangat luas (Sugiyono, 2017:121). Satu kelas untuk try out yaitu kelas XII MIPA 7 dan ada duakelas yang menjadi kelompok eksperimen dan kelompok kontrol, yaitu kelas XII IPS 1 dan XII IPS 2

b. Melakukan try out skala manajemen waktu belajar di kelas XII MIPA 7 SMA Negeri 9 Semarang yang berjumlah 32 siswa untuk menguji validitas dan reliabilitas.

c. Melakukan pre-test terhadap kelas XII IPS 1 dengan jumlah siswa 36 dan XII IPS 2 dengan jumlah 36 siswa. Selanjutnya kelas yang diberi pre-test akan dipilih masing-masing 10 siswa sebagai kelompok kontrol dan kelompok eskperimen dengan menggunakan simple random sampling. Dikatakan simple 
(sederhana) karena pengambilan anggota sampel dari populasi dilakukan secara acak tanpa memperhatikan strata yang ada dalam populasi itu (Sugiyono, 2015:120)

d. Berdasarkan data pre-test terhadap kelas XII IPS 1 dan XII IPS 2 dengan skala manajemen waktu belajar dengan menggunakan rentang skor 1 sampai 4.

2. Pelaksanaan Eksperimen

a. Setelah menentukan 10 siswa dari kelas XII IPS 1 dan XII IPS 2, selanjutnya menentukan kelompok eksperimen dan kelompok control dari kedua kelas tersebut. Dimana kelas XII IPS 1 sebagai kelompok eksperimen dan kelas XII IPS 2 sebagai kelompok kontrol

b. Sesudah ditetapkan kelompok kontrol dan kelompok eksperimen, kemudian kelompok control diberikan tindakan oleh guru BK dan kelompok eksperimen diberikan layanan bimbingan kelompok dengan teknik simulation games oleh peneliti

c. Treatment dilaksanakan terhadap kelompok eksperimen sebanyak 5 kali. Sedangkan kelompok control diberikan layanan oleh guru BK.

3. Akhir Eksperimen

a. Sesudah mendapatkan perlakuan, maka pada kelompok eksperimen dan kelompok control diberikan post-test, guna mengetahui adakah perbedaan antara kelompok kontrol dan kelompok eksperimen.

b. Selanjutnya peneliti melakukan analisis menggunakan uji-t untuk mengetahui pengaruh layanan bimbingan kelompok dengan teknik simulation games.

\section{HASIL PENELITIAN DAN PEMBAHASAN}

Berdasarkan perthitungan uji hipotesis diperoleh $t_{\text {hitung }}=2,966$. Selanjutnya dikonsultasikan dengan $\mathrm{dk}=$ 18 dan taraf signifikansi 5\% diketahui $t_{\text {tabel }}$ $=2,101$ sehingga $t_{\text {hitung }}>t_{\text {tabel }}, 2,966>$ 2,101. Dengan demikian Ho ditolak dan Ha diterima.Oleh karena itu hipotesis yang berbunyi "ada pengaruh bimbingan kelompok dengan teknik simulation games untuk meningkatkan manajemen waktu belajar siswa kelas XII SMA Negeri 9 Semarang" diterima kebenarannya.

Analisis hasil pre-test antara kelompok eksperimen dan kelompok control menunjukkan bahwa tidak ada perbedaan yang signifikansi antara kelompok eksperimen dan kelompok kontrol. Rata-rata kelompok eksperimen sebesar69,0 menjadi77,1 terjadi peningkatan 8,1. Sedangkan pada kelompok control dari 68,5 menjadi 69,0 terjadi peningkatan sebesar 0,8. Selisih antara kelompok eksperimen dan kelompok control yaitu7,3. Hasil analisis data menunjukkan bahwa ada perbedaan antara kelompok eksperimen yang diberikan treatment berupa layanan bimbingan kelompok dengan menggunakan teknik simulation games, sedangkan kelompok control tidak diberikan treatment.

Penelitian ini membahas mengenai manajemen waktu belajar siswa, hal ini ditunjukan dengan rendahnya kemampuan manajemen waktu belajar siswa baik di sekolah maupun di rumah. Permasalahan 
yang sering dialami siswa diantaranya kesulitan dalam mengatur waktu untuk belajar, sering kali ditemui masalah kekurangan waktu bagi siswa menjadi alas an untuk tidak terselesaikannya suatu tugas, mengerjakan tugas dengan system kebut semalam, hampir setiap hari tidak lepas dari tugas-tugas sekolah dan terkadang terlambat dalam mengumpulkan tugas, saatakan ulangan biasanya belajar di pagi harinya. Dari beberapa siswa mereka sudah membuat jadwal kegiatan sehari-hari tetapi kadang tidak berjalan sesuai dengan yang sudah direncanakan, bagi siswa menganggap semua kegiatan dan aktifitasnya itu penting sehingga siswa belum mampu memfokuskan dan memprioritaskan suatu tugas tertentu.Untuk meningkatkan manajemen waktu belajar siswa maka digunakan layanan bimbingan kelompok dengan teknik simulation games.

Nurihsan (2014:23) menyatakan bimbingan kelompok merupakan bantuan terhadap individu yang dilaksanakan dalam situasi kelompok. Bimbingan kelompok dapat berupa penyampaian informasi ataupun aktivitas kelompok membahas masalah-masalah pendidikan, pekerjaan, pribadi dan sosial. Pemberian informasi dalam bimbingan kelompok terutama dimaksudkan untuk meningkatkan pemahaman tentang kenyataan, aturan-aturan dalam kehidupan, cara-cara yang yang dilakukan untuk menyelesaikan tugas. Bimbingan melalui aktivitas kelompok lebih efektif karena selain peran individu lebih aktif, juga memungkin kanter jadinya pertukaran pemikiran, pengalaman, rencana dan penyelesaian masalah. Menurut Hasibuan dan Moedjiono (dalam Taniredja, dkk 2015:39) simulasi adalah tiruan atau perbuatan yang hanya purapura saja. Senada dengan Majid (2014:206) Simulasi game merupakan bermain peranan, para siswa berkompetisi untuk mencapai tujuan tertentu melalui permainan dengan mematuhi peraturan yang ditentukan. Bimbingan kelompok dengan teknik simulation games yaitu layanan bantuan terhadap individu maupun penyampaian informasi berkaitan dengan masalah-masalah tertentu dalam situasi kelompok dengan menggunakan permainan yang dimaksudkan untuk merefleksikan situasi-situasi dalam kehidupan sebenarnya dengan memadukan diskusi, yang diharapkan siswa mampu meningkatkan manajemen waktu belajar. Pemberian treatment dilaksanakan sebanyak 5 pertemuan, dalam treatment anggota kelompok melaksanakan simulation games sesuai dengan topik yang dibahas, kemudian berdiskusi bersama untuk membahas makna dari simulation games yang dimainkan serta merefleksikan dengan aktivitas sehari-hari.

Dari uraian di atas dapat disimpulkan bahwa bimbingan kelompok dengan teknik simulation games dapat meningkatkan manajemen waktu belajar siswa kelas XII SMA Negeri 9 Semarang.

\section{SIMPULAN}

Berdasarkan penelitian yang sudah dilakukan, diperoleh kesimpulan sebagai berikut: Tingkat manajemen waktu belajar sesudah diberikan treatment bimbingan kelompok dengan teknik simulation games menjadi meningkat, hal ini ditunjukan dengan hasil perhitungan analisis data post-test diketahui skor ratarata kelompok eksperimen manajemen 
waktu belajar menjadi meningkat dari 69,0 menjadi 77,1 setelah dilaksanakannya treatment. Pada kelompok eksperimen terjadi peningkatan sebesar 8,1. Sedangkan untuk skor perindikator terjadi peningkatan tertinggi pada indicator kedua yaitu pentingnya mengatur waktu dalam melakukan aktivitas dari 20,8 menjadi 24,2 terjadi peningkatan sebesar 3,4.

1. Bimbingan kelompok dengan teknik simulation games berpengaruh untuk meningkatkan manajemen waktu belajar siswa kelas XII SMA Negeri 9 Semarang, hal ini dibuktikan dengan uji $t$ yang memperoleh hasil sebesar $t_{\text {hitung }} 2,966$. Selanjutnya dikonsultasikan dengan tabel $\mathrm{dk}=\mathrm{n}_{1}+\mathrm{n}_{2}=18$ dan taraf signifikan $5 \%$ dengan $t_{\text {tabel }}=2,101$. Maka $t_{\text {hitung }}>t_{\text {tabel }}$, $2,966>2,101$

Melihat hasil penelitian, saran-saran yang diajukan peneliti adalah : Diharapkan dengan adanya layanan bimbingan kelompok dengan teknik simulation games ini siswa mampu meningkatkan kemampuan manajemen waktu belajar dan menggunakan waktu dengan efisien, dapat membagi waktu antara kegiatan utama dan kegiatan selingan lain dengan optimal. Mampu menambah wawasan serta pengalaman bagi siswa dalam pelaksanaan layanan bimbingan kelompok dengan teknik simulation games untuk meningkatkan manajemen waktu belajar.

\section{DAFTAR PUSTAKA}

Hamalik, Oemar. 2009. PsikologiBelajar dan Mengajar.

Bandung:SinarBaruAlgensindo

Hartinah, Sitti. 2009. Konsep Dasar BimbinganKelompok. Bandung: PT
RefikaAditama

Haynes, E Marion. 2010. Manajemen Waktu. Jakarta: PT Indeks

Jailani, Muhammad. 2019. Hubungan Status Sosial Ekonomi Orang Tua Terhadap Motivasi Anak Untuk Berwirausaha. Pedagogik: Jurnal Pendidikan, 14(1):35-42.

Karyanti, Muhammad Andi Setiawan. 2018. Model Konseling Kelompok Teknik Expresif Writing Berlandaskan Falsafah Dandang Tingang Untuk Meningkatkan Perilaku Respect. JURKAM: Jurnal Konseling Andi Matappa, 2(2):129136.

Majid,

Abdul.

2014.

StrategiPembelajaran. Bandung:

RemajaRosdaKarya

Nurihsan, AchmadJuantika. 2014. Bimbingan dan

Konselingdalamberbagailatarkehid upan. Bandung: PT RefikaAditama

Prayitno dan Erman Amti. 2008. Dasar-

Dasar Bimbingan dan Konseling. Jakarta: PT RINEKA CIPTA

Putra, Chandra Anugrah. 2016. Pengaruh Strategi Pembelajaran Berbasis Proyek Perancangan dan Kecerdasan Logik-Matematik Terhadap Kompetensi Merancang Web. Jurnal Teknologi Pendidikan, 18(2):90-101.

Putra, Chandra Anugrah. 2016. Pengaruh Strategi Pembelajaran Berbasis Proyek Perancangan dan Kecerdasan Logik-Matematik Terhadap Kompetensi Merancang Web. Jurnal Teknologi Pendidikan, 18(2):90-101.

Riadin, Agung \& M. Jailani. 2019. Perbedaan Peningkatan Hasil Belajar Ekonomi Dengan Menerapkan Model Cooperatif Tipe

Ulfa Luthfiyanti*, Supardi**, dan Agus Setiawan***

Fakultas Ilmu Pendidikan

Universitas PGRI Semarang 
NHT (Numbered Head Together) Dan Tipe IOC (Inside Outside Circle) Pada Peserta Didik SMA Muhammadiyah 1 Palangkaraya. Pedagogik: Jurnal Pendidikan 14(2):60-70.

Riadin, Agung. 2019. Implementasi Pembelajaran PKn untuk Membentuk Pribadi yang Berkarakter di SD Muhammadiyah Sampit. Pedagogik: Jurnal Pendidikan, 14(1):18-28.

Romlah, Tatiek. 2001. Teori dan Praktek BimbinganKelompok. Malang: Universitas Negeri Malang

Setiawan, M Andi. 2015. Model konseling kelompok dengan teknik problem solving untuk meningkatkan selfefficacy akademik siswa. Jurnal Bimbingan Konseling 4(1).

Setiawan, M Andi. 2015. Model konseling kelompok dengan teknik problem solving untuk meningkatkan selfefficacy akademik siswa. Jurnal Bimbingan Konseling 4(1).

Slameto. 2013. Belajar dan Faktor-faktor yang Mempengaruhi. Jakarta: PT RINEKA CIPTA.

Srijanti, dkk. 2006. Etika Membangun Sikap Profesionalisme Sarjana. Jakarta: Grahallmu

Sugiyono. 2015. Metode Penelitian Pendidikan. Bandung: Alfabeta

Sugiyono. 2017. Metode Penelitian Pendidikan. Bandung: Alfabeta

Surya, Mohammad. 2014. Psikologi Guru Konsep dan Aplikasi dari Guru, untuk Guru. Bandung: Alfabeta

Taniredja, dkk. 2015. Model-Model Pembelajaran Inovatif dan Efektif. Bandung: Alfabeta. 